\title{
Parameters determination of a conceptual rainfall-runoff model for a small catchment in Carpathians
}

\author{
BEATA KARABOVÁ ${ }^{1}$, ANNA E. SIKORSKA ${ }^{2}$, KAZIMIERZ BANASIK $^{2}$, SILVIA \\ KOHNOVÁ \\ ${ }^{1}$ Department of Land and Water Resources Management, Faculty of Civil Engineering, Slovak University of \\ Technology, Bratislava, Slovakia \\ ${ }^{2}$ Department of Water Engineering, Faculty of Civil and Environmental Engineering, Warsaw University of Life \\ Sciences-SGGW, Warsaw, Poland
}

\begin{abstract}
Parameters determination of a conceptual rainfall-runoff model for a small catchment in Carpathians. One of the most important tasks in hydrology is to simulate and forecast hydrologic processes and variables. To achieve this, various linear and nonlinear hydrologic models were developed. One of the most commonly applied rainfall-runoff models is the Nash's model of the Instantaneous Unit Hydrograph (IUH) (Nash, 1957) used jointly with the CN-NRCS method. Within this paper, the Nash's model was applied to a small forested basin (Vištucký Creek, Slovakia) to reconstruct rainfall-runoff events based on the recorded precipitation. The Vištucký Creek catchment, located in the Little Carpathians, is a part of the flood protection management of regional sites in the Little Carpathians. Therefore, the object of this paper is, first, to determine the parameters of a conceptual rainfall-runoff model for the Vištucký creek catchment, second, to analyse how the selected characteristics of the model depend on the rainfall characteristics, and third, to compare obtained results with a similar study of Sikorska and Banasik (2010). The computer programme developed at the Dept. of Water Engineering (WULS-SGGW) was used to obtain the rainfall-runoff characteristics based on the Nash's model. The derived characteristics were parameters of the Nash's model $(N, k$, lag time) and rainfall-runoff characteristics (sum of total and effective precipitation, rainfall duration, runoff coefficient, time to IUH peak, value of IUH peak, goodness of fit). A relatively small effective precipitation from the rainfall events was derived. For the purpose of the analysis, a correlation between the lag time (and $k$ parameter) and the sum of the total and effective precipitation was used. The use of the conceptual rainfall-runoff model (Nash's model) for the small catchment in Carpathians was proved to give satisfactory results. The rainfall characteristics derived in this study are comparable to the results obtained by Spál et. al (2011), who used the same catchment in their analysis. Interestingly, our analysis indicated that there is a correlation between the rainfall duration and the lag time, what is opposite to the compared results of Sikorska and Banasik (2010).
\end{abstract}

Keywords: conceptual rainfall-runoff model, Lag time, small catchment

\section{INTRODUCTION}

Estimating an appropriate design value for extreme flood events such as maximum water levels, discharges, or runoff is one of the most important tasks of the design process for a large number of engineering projects and studies. Flood estimation requires, however, consideration of geographic conditions, jurisdictional requirements, hydrological and meteorological data. Unfortunately, many different methodologies developed and various countries have adopted different procedures and hydrological models that fit the conditions and requirements of particular countries. In addition, many small catchments around the world suffer from the lack of recorded data. Therefore, a selection of the proper method is often dictated by the size of the catchment and the data availability.

A significant problem may arise in small catchments that are poorly gauged or when no recorded data exist. In such situations, when distributed models fail, conceptual models still meet the conditions and therefore are often used. Such models have a limited number of parameters, which can be derived from empirical equations or generally available data. A commonly used form of a conceptual rainfall-runoff model to predict discharges in poorly gauged catchments is Nash's model of the Instantaneous Unit Hydrograph (IUH) (Nash, 1957). This model uses a concept of a catchment described as a cascade of linear reservoirs, 
which parameters may be inferred from empirical equations (Sikorska et al., 2012). A computer programme to deliver rainfall-runoff characteristics based on the Nash's model was developed by Banasik (1994) at the Dept. of Water Eng., WULS-SGGW. Sikorska and Banasik (2010) further verified the chosen characteristics of the model in an analysis of a small urban catchment in Poland and their dependence on the rainfall characteristics.

The object of this paper is, therefore, first - to determine the parameters of the applied conceptual rainfall-runoff model based on few recorded events, second - to analyze relations between model parameters and rainfall characteristics, and third - to compare results of Vištucký Creek with a similar study of a small urbanised basin (Służew Creek) in Poland (Sikorska and Banasik 2010).

\section{MATERIAL AND METHODS}

The study was carried out on a small catchment in the Little Carpathians (Vištucký Creek). The Vištucký creek is a tributary to the Čierna Voda, which flows to the river Danube. The catchment area of the Vištucký creek to the Modra gauging station is $9.8 \mathrm{~km}^{2}$ and the length of the stream is $5.4 \mathrm{~km}$. The altitude of the basin varies from $500 \mathrm{~m}$ a.s.l. (spring at the northern border of town Modra, part Piesok and Harmonia) to $280 \mathrm{~m}$ a.s.l. (Modra profile). The significant part of the catchment (90\%) is covered with the oak forest and the rest of the territory is formed by roads and sports complex in the upper basin.

For the purpose of this study, there were available rainfall data from the rain gauging station (18050 Modra- Harmónia) and discharge data from the stream gauge station (5210 Modra) from a five-year period (2005-2010). During recorded period 20 rainfall-runoff events were observed, of which 12 had discharge over $0.4 \mathrm{~m}^{3} \mathrm{~s}^{-1}$ and one over $1.6 \mathrm{~m}^{3} \mathrm{~s}^{-1}$. Three events were directly rejected from the further analysis due to a long duration of rainfall which exceeded 24 hours. Finally, nine events in the period of 2005-2010 have been chosen for the rainfall-runoff analysis. An interval time step was 60 minute (frequency of recording data). These data had been previously collected for the project titled "Creation and development of environmental technologies for flood protection of the Little Carpathian regional sites - Modra case study", where the SCS CN methodology was tested (Spál et al., 2011).

The Nash model of Instantaneous Unit Hydrograph (IUH) (Nash, 1957) was selected to transform observed rainfall into observed runoff. As a conceptual model with limited number of parameters, the Nash's model is still frequently used in ungauged or sparse data catchments (Sikorska et al., 2012). This model uses an approach in which a catchment is described as a cascade of $N$ linear reservoirs with a retention parameter $k$ of each reservoir. The IUH is here described as a two-parameters gamma probability density function (with $N \& k$ parameters). The effective precipitation is then transformed through the cascade of $N$-reservoirs to produce surface runoff at the outlet of the catchment. The model's equations are presented below.

$u(t)=\frac{1}{k \Gamma(N)} \cdot\left(\frac{t}{k}\right)^{N-1} \exp \left(-\frac{t}{k}\right)$

where:

$\mathrm{u}(\mathrm{t})$ - ordinates of IUH $\left[\mathrm{h}^{-1}\right]$,

$\mathrm{t}$ - time from the beginning of the coordinate system [h],

$\mathrm{N}$ - number of linear reservoirs,

$\mathrm{k}$ - retention parameter of each reservoir [h],

$\Gamma(\mathrm{N}) \quad$ - gamma function.

Rainfall-runoff characteristics (as discharge peak, a time to the peak and a lag time) of recorded events are computed based on the Nash's model by the SN computer programme developed at the Dept. of Water Eng. of WULS-SGGW (Banasik, 1994). Those characteristics may be of a high importance in hydraulic engineering, e.g. to design of culverts or bridges. Lag time describes a delay in the catchment response to the occurred rainfall event (time between the centre of the effective rainfall hyetograph and the direct runoff hydrograph). Those characteristics can be approximated by the characteristic values of IUH hydrograph as described: 
$t_{p i}=k_{i} \cdot\left(N_{i}-1\right)$

$u_{(t p i)}=\frac{1}{k_{\mathrm{i}} r\left(N_{i}\right)} \cdot \frac{\left(\mathrm{N}_{\mathrm{i}}-1\right)}{\exp \left(\mathrm{N}_{\mathrm{i}}-1\right)}$

where:

$\mathrm{t}_{\mathrm{pi}} \quad$ - time to IUH peak for i-event [h],

$\mathrm{u}\left(\mathrm{t}_{\mathrm{pi}}\right)$ - value of IUH peak for i-event $\left[\mathrm{h}^{-1}\right]$,

$\mathrm{N}_{\mathrm{i}}$ - number of linear reservoirs for i-IUH,

$\mathrm{k}_{\mathrm{i}} \quad$ - retention parameter of reservoir for i-IUH [h],

$\Gamma(\mathrm{N}) \quad$ - gamma function.

The lag time is computed, using the statistical moments method with the formula:

$$
\begin{aligned}
& L a g=M_{1 Q}-M_{1 P} \\
& M_{2 Q}-M_{2 P}=N \cdot k^{2} \cdot(N+1)+2 N \cdot k \cdot M_{1 P} \\
& N \cdot k=M_{1 Q}-M_{1 P}
\end{aligned}
$$

where $M_{1 Q}$ and $M_{1 P}$ are the first and $M_{2 Q}$ and $M_{2 P}$ are the second statistical moments of the direct runoff hydrograph (outlet) and effective rainfall hyetograph (input) (Singh 1988).

The relationship between the lag time and the Nash model parameters is then expressed as:

$$
\operatorname{Lag}=\mathrm{N} \cdot \mathrm{k}
$$

For the selected events, the parameters and characteristics of the IUH were calculated on the basis of rainfall and runoff recorded data by the method of statistical moments (Equations 4-7). The average values of the IUH peak and time to the IUH peak over all events were estimated as an arithmetical average.

The effective rainfall was separated from the observed total precipitation, based on the CN-SCS method (USDA, 1986).

$$
C N=\frac{25400}{s+254}
$$

where $S$ is the catchment storage parameter $[\mathrm{mm}]$ computed from the recorded total and effective precipitation from the formula:

$S=5\left(P+2 H-\left(4 H^{2}+5 P H\right)^{0.5}\right)$

$P \quad$ - rainfall depth $[\mathrm{mm}]$,

$H$ - effective rainfall depth assumed equal to direct runoff, determined after subtracting the base flow volume $[\mathrm{mm}]$.

To assess the goodness of fit of the computed hydrographs to the measured ones, two coefficients were estimated (Sikorska and Banasik, 2010): 


$$
\begin{aligned}
& R=\frac{n \cdot \sum_{i=1}^{n} Q_{O(i)} \cdot Q_{C(i)}-\left(\sum_{i=1}^{n} Q_{O(i)}\right) \cdot\left(\sum_{i=1}^{n} Q_{C(i)}\right)}{\left[n \cdot \sum_{i=1}^{n}\left(Q_{O(i)}\right)^{2}-\left(\sum_{i=1}^{n} Q_{O(i)}\right)^{2}\right] \cdot\left[n \cdot \sum_{i=1}^{n}\left(Q_{C(i)}\right)^{2}-\left(\sum_{i=1}^{n} Q_{C(i)}\right)^{2}\right]} \\
& R S=\left[\frac{2 \cdot \sum_{i=1}^{n} Q_{O(i)} \cdot Q_{C(i)}-\sum_{i=1}^{n}\left(Q_{C(i)}\right)^{2}}{\sum_{i=1}^{n}\left(Q_{O(i)}\right)^{2}}\right]^{1 / 2}
\end{aligned}
$$

where: $Q_{O(i)}$ and $Q_{C(i)}$ are the i-th observed and computed flow values, $n$ is a number of values in the flow series.

\section{RESULTS AND DISCUSSION}

For the nine selected rainfall-runoff events (the Vištucký Creek catchment) parameters and characteristics of the IUH were derived with the Nash model using the method of statistical moments (and the developed SN program). The total precipitation (Pm) for selected events varied from 19.6 to $45 \mathrm{~mm}$. The duration of the rainfall (D) was 4 to 19 hours, with an average value of 8.2 hours. The range of the Lag time (Lag)values varied from 2.36 to $5.47 \mathrm{~h}$. The average lag time of the Vištucký Creek catchment was 4.42 hours, what seems reasonable for a small (forest) catchment. Surprisingly, the lowest value of the lag time was during the ninth event, for which the duration of the rainfall was the longest (19 hours). This event, however, had the second highest observed effective rainfall Peff (see table 1). The correlation coefficients (R, RS) indicate good fit of the computed hydrographs to the measured ones.

\begin{tabular}{|c|c|c|c|c|c|c|c|c|c|c|c|c|c|c|}
\hline \multirow{3}{*}{ No. } & \multirow{3}{*}{ Date } & \multicolumn{5}{|c|}{ Rainfall-runoff characteristics } & \multicolumn{6}{|c|}{ IUH characteristics - SCS-CN } & \multirow{2}{*}{\multicolumn{2}{|c|}{$\begin{array}{l}\text { Correlation } \\
\text { coefficients }\end{array}$}} \\
\hline & & $\mathrm{Pm}$ & Peff & $\mathrm{D}$ & $\begin{array}{l}\text { Runof } \\
\text { f max }\end{array}$ & $\begin{array}{l}\text { runoff } \\
\text { coeff. }\end{array}$ & $\mathrm{CN}$ & $\mathrm{N}$ & $\mathrm{k}$ & Lag & Tim & Valu & & \\
\hline & & $(\mathrm{mm})$ & $(\mathrm{mm})$ & (h) & {$[\mathrm{m} 3 / \mathrm{s}]$} & $(-)$ & $(-)$ & $(-)$ & (h) & (h) & (h) & $(1 / \mathrm{h})$ & $\mathrm{R}$ & $\mathrm{RS}$ \\
\hline 1 & 25.7.2005 & 34.5 & 0.45 & 4 & 0.488 & 0.013 & 65.67 & 12 & 0.46 & 5.47 & 5.01 & 0.262 & 0.957 & 0.963 \\
\hline 2 & 27.8 .2005 & 26.9 & 0.46 & 12 & 0.32 & 0.017 & 71.87 & 4.21 & 1.19 & 5.01 & 3.81 & 0.183 & 0.986 & 0.991 \\
\hline 3 & 11.9 .2005 & 23.5 & 0.74 & 6 & 0.686 & 0.031 & 76.57 & 5.42 & 0.85 & 4.59 & 3.74 & 0.22 & 0.923 & 0.939 \\
\hline 4 & 3.8 .2006 & 45 & 0.19 & 10 & 0.256 & 0.040 & 56.63 & 5.74 & 0.58 & 3.33 & 2.75 & 0.31 & 0.936 & 0.948 \\
\hline 5 & 6.6 .2007 & 19.6 & 0.32 & 4 & 0.162 & 0.016 & 77.66 & 3.04 & 1.66 & 5.04 & 3.38 & 0.162 & 0.902 & 0.936 \\
\hline 6 & 10.6.2007 & 39.3 & 0.9 & 5 & 0.611 & 0.023 & 64.73 & 7.45 & 0.62 & 4.65 & 4.03 & 0.248 & 0.996 & 0.997 \\
\hline 7 & 25.6.2008 & 36.6 & 1.51 & 5 & 1.720 & 0.041 & 69.09 & 7.32 & 0.7 & 5.14 & 4.43 & 0.223 & 0.858 & 0.879 \\
\hline 8 & 20.7.2008 & 31.1 & 0.72 & 9 & 0.548 & 0.023 & 69.93 & 12 & 0.35 & 4.24 & 3.89 & 0.338 & 0.977 & 0.981 \\
\hline 9 & 23.7 .2008 & 34.6 & 1.27 & 19 & 0.483 & 0.037 & 69.67 & 1 & 2.36 & 2.36 & 0 & 0.424 & 0.743 & 0.771 \\
\hline \multicolumn{2}{|c|}{ Mean values } & 32.34 & 0.73 & 8.22 & 0.60 & 0.027 & 69.1 & 6.46 & 0.97 & 4.42 & 3.45 & 0.263 & 0.920 & 0.934 \\
\hline \multicolumn{7}{|c|}{ Standard deviation } & 6.36 & 3.73 & 0.66 & 0.99 & 1.44 & 0.082 & & \\
\hline
\end{tabular}

TABLE 1. Parameters and characteristics of the Nash model for nine rainfall-runoff events at the Vištucký Creek basin

In regards to the estimated curve number $(C N)$, computed values varied from 56.6 to 77.6 and the average for all events was estimated as 69.1. In other study of the same catchment Spál et al. (2011) determined curve numbers empirically according to the SCS methodology (USDA, 1986) for three different antecedent moisture conditions of saturation (AMC I, II, III), achieving $C N I=47, C N I I=67$ and $C N I I I=83$. 
The results of our study would therefore indicate on average the AMC of a catchment between II and III conditions.

The correlation between Nash parameters (lag time, $k$ ) and the sum of the precipitation (total and effective), a duration of the rainfall and the Curve number was estimated and is presented on the Figure 1. The correlation between the model characteristics and the rainfall characteristics is very low and seems to be independent, although there seems to be some dependence between the lag time and rainfall duration.
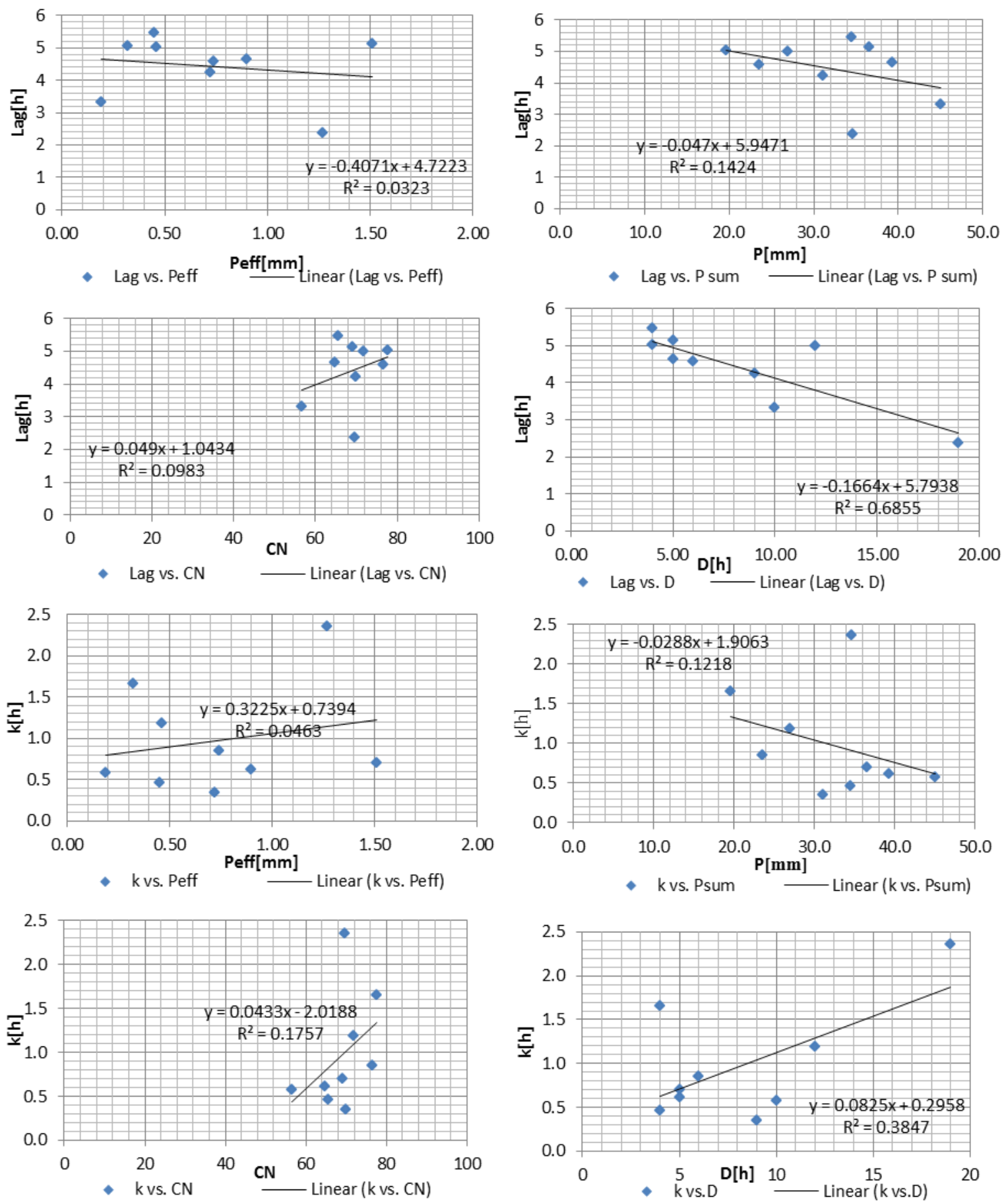

FIGURE 1. Correlation between the Nash parameters and rainfall characteristics (Vištucký creek) 
Achieved results for the Vištucký creek were compared with the study of Sikorska and Banasik (2010), who conducted similar analyses but on a small urbanized catchment (Sluzew Creek) in Warsaw, Poland, with the area of $26.9 \mathrm{~km}^{2}$ and the impervious areas ratio of $23.7 \%$. For the Sluzew Creek catchment the average value of computed $C N$ was estimated as 87.8. That is in agreement with our results, where for a forest basin a smaller $C N$ value is expected. For the comparison of other characteristics between two catchments see Figure 2 .

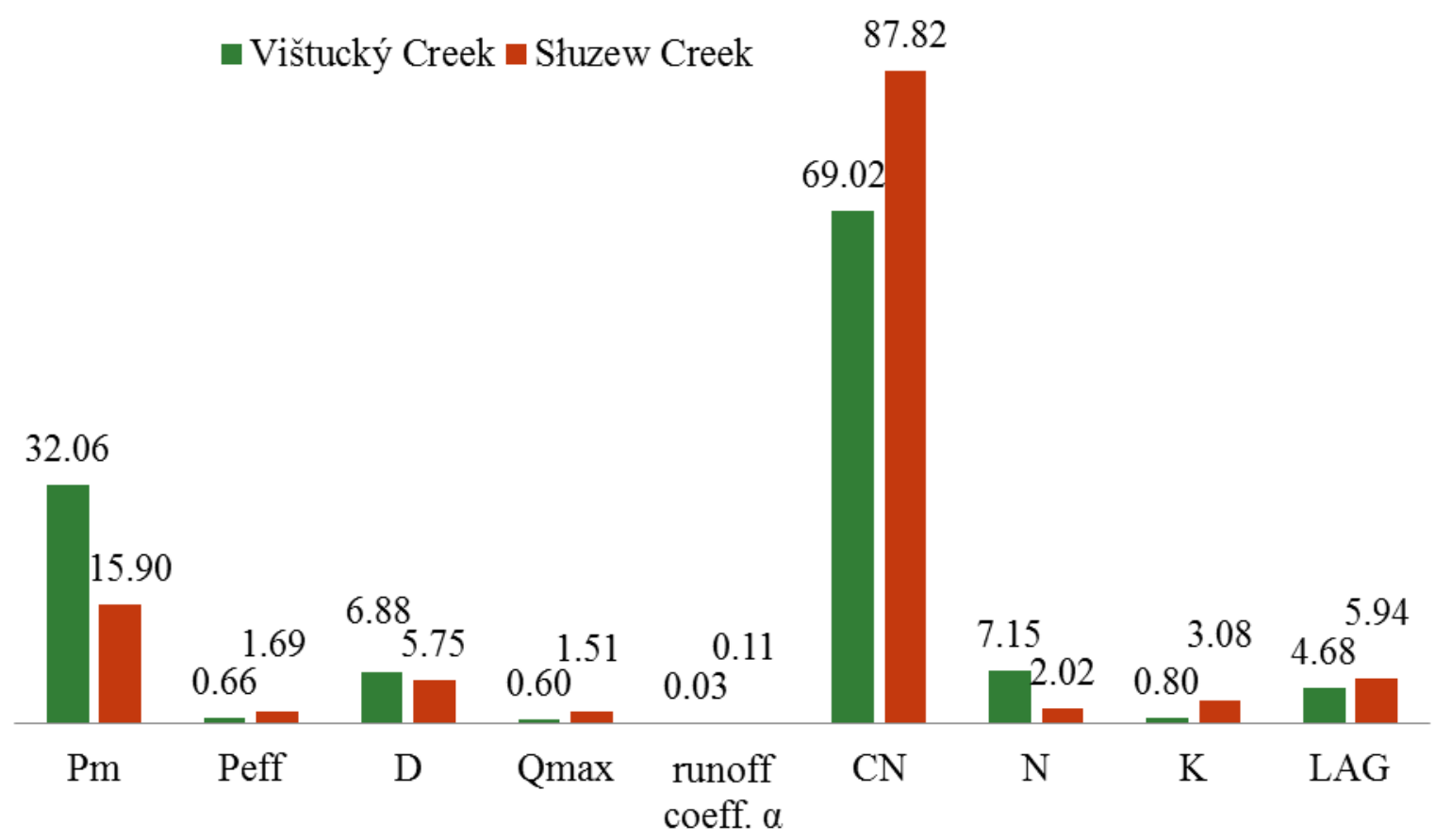

FIGURE 2. Comparison of the Nash parameters and rainfall characteristics between the two catchments (Vištucký creek and Sluzew creek)

\section{CONCLUSIONS}

Several conclusions could be derived from the results of this paper. First, the use of the conceptual rainfallrunoff model (Nash's model) for the small catchment in Carpathians was proved to give satisfactory results. A good agreement of the regenerated runoff hydrographs with the measured ones for 7 out of all 9 analysed events, what is a good achievement. In regards to rainfall-runoff characteristics of analysed events, a relatively small effective precipitation from the rainfall events was derived, with the mean runoff coefficient of 0.027, with the range of 0.013-0.041 and with mean $C N=69.1$. There was a relatively stable lag time for 7 out of all 9 analysed events with mean of 4.42 hours (ranging from 2.36 to $5.47 \mathrm{~h}$ ).

Second, the correlation between the model characteristics and the rainfall characteristics is very low and seems to be independent, although there seems to be some dependence between the lag time and rainfall duration. The computed $C N$ value $(C N$ mean $=69.1)$ was similar to the theoretical value $(C N I I=67)$ derived from empirical equations (Spál et al., 2011). The method used to derive the effective rainfall (SCS-CN), however, has numerous questionable features that need further investigation, (e.g. the problems with determining curve numbers arise, when using events in which runoff is a small fraction of the rainfall. (Hjelmfelt, 1991); the unit hydrographs of small catchments are strongly affected by a land use type (Holland, 1969); a formal procedure has not been derived for forested watersheds (McCutcheon, 2003); the method does not take the spatial and temporal variability of infiltration and other abstractive losses into account (Ponce and Hawkins, 1996)).

Third, in the Vištucký Creek there were events characterized by roughly similar rainfall duration as for the Sluzew catchment, but rather larger total rainfall. The comparison between the average values showed that 
the lag time in the Vištucký Creek was shorter than in the Sluzew Creek (Fig. 2). When individual events were compared, the differences in the effective rainfall were observed, which relates to different curve numbers. In the study of Sikorska and Banasik (2010) a statistical correlation between the precipitation (total and effective) and the Nash's model parameters (Lag, $k$ ) was observed, however, no correlation between the Nash parameters and the rainfall duration. Differently, in this study of Vištucký Creek a statistical correlation between the Nash's model parameters $(\mathrm{Lag}, k)$ and the duration of rainfall $(0.685,0.385)$ was observed, and no correlation between the Nash's model parameters ( $L a g, k)$ and the precipitation (less than 0.1 ).

The results obtained in this study could be useful for the flood prevention purposes of this particular catchment. To generalize results, however, further investigation is needed and will involve the determination of the characteristics and parameters for another small Carpathian catchments. In addition, extending data sample by higher number of events with the similar rainfall characteristics could verified achieved results.

\section{Acknowledgment}

The investigation described in the contribution has been initiated byfirst Author research visit to Warsaw University of Life Sciences - SGGW within a STSM of the COST Action ES0901.

This work has been supported by Grant No. APVV 0496-10 and by PL-NCN as part of research project nr: NN305 396238.

\section{REFERENCES AND SUMMARY}

BANASIK, K. 1994: Model sedymentogramu wezbrania opadowego w małej zlewni rolniczej [Sediment graph model of a rainfall event in a small agricultural watershed]. Publication of Warsaw Agricultural University - SGGW, p. 120.

HJELMFELT, JR, A.T. 1991: Investigation of curve number procedure. Journal of Hydraulic Engineering Division, Amer Soc Civ Eng, 117 (6), 725-737.

HOLLAND, M.E. 1969: Runoff from forest and agricultural watersheds. Ft. Collins, Colo. : Natural Resources Center, Colorado State University, Completion Report Series 4, 22.

McCUTCHEON, S.C. 2003: Hydrologic evaluation of the Curve Number Method for forest management in West Virginia. Report prepared for the West Virginia Division of Forestry, Charleston, West Virginia.

NASH, J. E. 1957: The form of instantaneous unit hydrograph. Surface Water. Prevision. Evaporation International Association of Sciences and Hydrological Publications, 45, 114-121.

PONCE, V. M., HAWKINS, R. H. 1996: Runoff curve number: Has it reached maturity? Journal of Hydrologic Engineering, ASCE, 1 (1), 11-19.

SIKORSKA, A., BANASIK, K. 2010: Parameter identification of conceptual rainfall-runoff model for a small urban catchment. Ann. Warsaw Univ. of Life Sci. - SGGW. Land Reclam. 42 (2), 279-293.

SIKORSKA, A. E., SCHEIDEGGER, A., BANASIK, K., RIECKERMANN, J. 2012: Bayesian uncertainty assessment of flood predictions in ungauged urban basins for conceptual rainfall-runoff models. Hydrol. Earth Syst. Sci. doi:10.5194/hess-16-1221-2012, 16, 1221-1236.

SINGH V.P. 1988: Hydrologic Systems. Vol. I. Rainfall-runoff modelling. Prentice-Hall. New Jersey. 
SPÁL, P., DANÁČOVÁ, M., SZOLGAY, J., HLAVČOVÁ, K. 2011: K neistotám výpočtu priameho odtoku metódou čísel odtokových kriviek (SCS CN) na príklade povodia Vištuckého potoka [The estimation of direct runoff using the curve number method (SCS CN) in the vištucký creek catchment]. Acta Hydrologica Slovaca, ISSN 1335-6291, 12 (2), 368-376.

USDA, SOIL CONSERVATION SERVICE 1986: Urban hydrology for small watersheds, Technical Release 55. USDA-SCS, Engineering Division, USGPS, Washington DC, USA.

Streszczenie: Określenie parametrów modelu konceptualnego opad-odpływ dla małej zlewni w Karpatach. Jednym $\mathrm{z}$ ważniejszych zagadnień $\mathrm{w}$ hydrologii jest matematyczne symulowanie i prognozowanie procesów hydrologicznych, które musi być poprzedzone wyznaczeniem parametrów stosowanych modeli. Do matematycznego opisu procesów opad-odpływ w małych zlewniach opracowano szereg modeli liniowych i nieliniowych o różnym stopniu złożoności. Jednym z częściej stosowanych jest model liniowy, w którym opad efektywny wyznaczany jest wg metody CN (Curve Number), stosowanej w Służbie Ochrony Zasobów Naturalnych (Natural Rsources Conservation Service) Departamentu Rolnictwa USA, a do transformacji opadu efektywnego w odpływ bezpośredni wykorzystywany jest chwilowy hydrogram jednostkowy (IUH) wg Nasha. Model ten zastosowano do odtworzenia zdarzeń opad-odpływ w małej leśnej zlewni górskiej Vištucký Potok w Małych Karpatach w zachodniej Słowacji. Celem przeprowadzonych badań było, po pierwsze - wyznaczenie parametrów zastosowanego modelu, na podstawie dziewięciu zarejestrowanych zdarzeń opad-odpływ w okresie 2005-2010, po drugie - zanalizowanie zależności parametrów modelu od charakterystyk deszczu, i po trzecie - porównanie wartości charakterystyk zdarzeń opad-odpływ i parametrów modelu z wynikami podobnego opracowania podobnego opracowania wykonanego dla zurbanizowanej zlewni Potoku Służewieckiego w Warszawie (Sikorska i Banasik 2010). Do wyznaczenia charakterystyk na podstawie zarejestrowanych zdarzeń opad-odpływ, parametrów modelu oraz do wyznaczenia hydrogramu "regenerowanego" i określenia parametrów jego zgodności z hydrogramem obserwowanym, wykorzystano program komputerowy SN opracowany w Katedrze Inżynierii Wodnej SGGW. Uzyskano zbieżność wyników w odniesieniu do parametru $C N$ (wartości średniej $\mathrm{z}$ analizowanych zdarzeń $\mathrm{z}$ wartością tablicową - ustaloną we wcześniejszych badaniach na podstawie rodzaju gleb i użytkowania terenu badanej zlewni) oraz stosunkowo małą zmienność czasu opóźnienia - Lag (iloczyny parametrów modelu Nasha: $N \mathrm{i} k$ ). Stosunkowa mała wartość parametru $\mathrm{CN}$ i współczynnika odpływu wynika z leśnego użytkowania zlewni. Uzyskano bardzo słabe zależności pomiędzy parametrami modelu i charakterystykami opadu. Porównanie wyników analizy zdarzeń opadowych w obydwu zlewniach potwierdza znacznie zróżnicowanie parametru $C N$ oraz wskazuje na małe różnice w czasie opóźnienia, determinowanego użytkowaniem, topografią i wielkością powierzchni zlewni.

Authors addresses:

\section{Beata Karabová}

Department of Land and Water Resources Management, Faculty of Civil Engineering, Slovak University of Technology, Radlinského 11, 81368 Bratislava, Slovakia, e-mail: beata.karabova@stuba.sk

Anna E. Sikorska

Department of Water Engineering, Faculty of Civil and Environmental Enginerring, Warsaw University of Life Sciences-SGGW, Nowoursynowska Street 166, 02-787, Warsaw, Poland, e-mail: anna_sikorska@sggw.pl 